\title{
Who's afraid of property rights? Rights as core concepts, coherent, prima facie, situated and specified ${ }^{1}$
}

Natural property rights are widely viewed as anathema to welfarist taxation, and are pictured as non-contextual, non-relational and resistant to regulation. Here, I argue that many of the major arguments for such views are flawed. Such arguments trade on an ambiguity in the term 'right' that makes it possible to conflate the core concept of a right with a situated or specified right from which one can read off people's actual legal entitlements and duties. I marshal several arguments demonstrating this conflation. In particular, I examine the right to free speech, where contextualization and responsiveness to the requirements of other rights are assumed as a matter of course. I conclude that the existence of one natural right does not foreclose the existence of other natural rights. Arguments for or against welfare rights must be assessed, at least to some extent, independently of the assertion of a natural property right.

\section{Introduction: the target arguments}

This section outlines the main arguments in political and legal theory that conflate the core concept of the right to property with the type of property right that can delineate actual legal entitlements and duties.

\footnotetext{
${ }^{1}$ This is a pre-publication version of: Breakey, Hugh. 'Who's Afraid of Property Rights? Rights as Core Concepts, Coherent, Prima Facie, Situated and Specified.' Law and Philosophy, DOI 10.1007/s10982-013-9190-5. The final publication is available at: http://link.springer.com/article/10.1007/s10982-013-9190-5.
} 
The first argument, familiar from the work of theorists such as Daniel Attas, Thomas Nagel and Liam Murphy, ${ }^{2}$ asserts the basic tension between natural property rights and a liability to expropriation through taxation.

\section{[Argument 1]}

Premise One: The core concept of the right to property does not contain modalities for expropriation, such as taxation for welfare purposes. (That is, liability for taxation is not part of the core concept of property; to the contrary, an essential feature of property is a broad immunity from expropriation.)

Premise Two: A welfare state, where resources are granted to the needy, is justified.

Conclusion: A natural right to property is unjustified.

Attas provides perhaps the most sophisticated argument of this type. His searching analysis of the core concept of property - illustrating the tight linkages between property's various incidents, and the problems bedevilling attempts to splice some incidents away - aims to justify the position that involuntary taxation is inconsistent with the right to property (whether natural or otherwise). As Attas avers: "no fiddling about with the incidents of ownership could change the simple fact that a property right cannot survive its

2 Daniel Attas, "Fragmenting Property", Law and Philosophy 25(1) (2007): 119-49; Liam Murphy and Thomas Nagel, The Myth of Ownership: Taxes and Justice (New York: Oxford University Press, 2002), pp. 44, 59-60, 73-4. Argument 1 also serves as a backdrop motivating the search for less expansive core concepts of property; for example John Christman, "Self-Ownership, Equality, and the Structure of Property Rights", Political Theory 19(1) (1991): 28-46. 
expropriation." ${ }^{3}$ If we cleave to welfarist and other forms of taxation, therefore, we must leave behind the right to property.

A similar argument may also be made with respect to regulation and contextualization:

\section{[Argument 2]}

Premise One: The core concept of the right to property is non-contextual, absolute and non-relational (in the sense of the right not being responsive to the needs of specific sorts of persons in specific situations with specific historical relationships).

Premise Two: Property entitlements existing in law and society are contextual, non-absolute and relational (in the above-noted sense). Environmental regulation is an obvious example of this. Moreover, it is justified that property rights are contextualized in these ways.

Conclusion: A natural right to property is unjustified. ${ }^{4}$

\footnotetext{
${ }^{3}$ Attas, "Fragmenting Property" p. 225.

${ }^{4}$ See John Oberdiek, "Lost in Moral Space: On the Infringing/Violating Distinction and Its Place in the Theory of Rights", Law and Philosophy 23 (2004): 325-46, p. 345; John Meyer, "The Concept of Private Property and the Limits of the Environmental Imagination", Political Theory 37 (2009): 99-127; Eric Freyfogle, "Private Property: Correcting the Half Truths", Planning and Environmental Law 59(10) (2007): 3-11; Eric Freyfogle, The Land We Share (London: Shearwater Books, 2003), esp. pp. 101-15.
} 
Instead of a natural right to property, the arguments above may be formulated in terms of a natural right of 'self-ownership', thus:

\section{[Argument 3]}

Premise One: The core concept of the right to property, as applied to one's own body and labour, does not contain modalities for expropriation, especially taxation for welfarist purposes, nor does it contain positive duties to others with respect to the property owned.

Premise Two: At least some positive duties with respect to others' welfare are justified.

Conclusion: A natural right of self-ownership is unjustified. ${ }^{5}$

Arguments 1 to 3 may be transposed to use a commitment to natural property rights (or natural self-ownership) to prohibit welfarist taxation and contextualized regulation:

\section{[Argument 4]}

Premise One: The natural right to property is justified.

Premise Two: The core concept of the right to property does not contain modalities for expropriation, such as taxation for welfarist purposes.

Conclusion: Taxation for welfarist purposes is unjustified.

\footnotetext{
${ }^{5}$ See Richard Arneson, "Lockean Self-Ownership: Towards a Demolition", Political Studies 39(1) (1991): 36-54, p. 54.
} 
It is perhaps fair to say that a certain amount of popular political discourse on taxation echoes Argument $4,{ }^{6}$ and I will take it as worthy of consideration for that reason. However, it needs to be underscored that - despite the clear libertarian conclusion of Argument 4 most contemporary libertarian philosophers do not rely on this sort of argument. Certainly, there are cases where analogues of Argument 4 play a supplementary role in larger arguments by libertarian theorists such as Murray Rothbard and Jan Narveson. ${ }^{7}$ So too, there are important passages where Robert Nozick speaks as if he accepts Argument $4 .^{8}$ Equally though, and as we will see, there are periods where Nozick is acutely sensitive to several of the objections I go on to raise against Argument $4 .^{9}$

\footnotetext{
${ }^{6}$ For the view that something like Argument 4 is a feature of lay and legal thinking about political theory, see Murphy and Nagel, Myth of Ownership; Charles Sampford and David
} Wood, "Tax, Justice and the Priority of Property", in W. Sadurski (ed.), Poznan Studies in the Philosophy of the Sciences and the Humanities (Amsterdam: Rodopi, 1991), pp. 181-208.

${ }^{7}$ Murray Rothbard, For a New Liberty: The Libertarian Manifesto, Rev. ed. (New York: Libertarian Review Foundation, 1978), 27-8; Jan Narveson, "Contracting for Liberty", in T. R. Machan and D. Rasmussen (eds.), Liberty for the Twenty-First Century (Lanham, Md.: Rowman \& Littlefield, 1995), pp. 19-41, pp. 26-7.

${ }^{8}$ Attas (Attas, "Fragmenting Property" p. 122) adverts to Nozick (Robert Nozick, Anarchy, State, and Utopia (Oxford: Basil Blackwell, 1974), pp. 160-4, 169-71) in his discussion of the “libertarian challenge" (here presented as Argument 4). However, Nozick's clearest use of Argument 4 emerges, I think, in his "filling the space of rights" argument: ibid., p. 238.

${ }^{9}$ Waldron perceptively notes the disparity between Nozick's claims in his "filling the space" argument, and his use earlier of the Lockean proviso. Jeremy Waldron, "Nozick and Locke: 
In terms of current philosophical argument, it is perhaps the version of Argument 4 premised on a natural right of 'self-ownership' that is most influential. G. A. Cohen's seminal work on self-ownership set the stage for a recent tradition that applied the core concept of property to people's own bodies and labours, ${ }^{10}$ leading that tradition to adopt either a libertarian ${ }^{11}$ or (more usually) a left-libertarian ${ }^{12}$ position. Based on this way of thinking, Argument 4 is almost axiomatic, with the conclusion that "no one owes a non-contracted service or product to anyone else" being held to follow necessarily from the assertion of self-ownership. ${ }^{13}$

Filling the Space of Rights", Social Philosophy and Policy 22 (2005): 81-110, p. 98-100. See Section $\mathrm{V}$ below.

${ }^{10}$ Gerald Cohen, Self-Ownership, Freedom and Equality (Cambridge: Cambridge University Press, 1995), esp. Chapters 3 and 4.

${ }^{11}$ E.g. Edward Feser, "There Is No Such Thing as an Unjust Initial Acquisition", Social Philosophy and Policy 22(1) (2005): 56-80.

${ }^{12}$ E.g. Michael Otsuka, "Self Ownership and Equality: A Lockean Reconciliation", Philosophy and public affairs 27(1) (1998): 65-92; Hillel Steiner and Peter Vallentyne, LeftLibertarianism and Its Critics: The Contemporary Debate (Basingstoke, Hampshire: Palgrave, 2000). Of course, there are many first-principles arguments for left-libertarianism that do not appeal to anything like Argument 4. See, for example, Hillel Steiner, An Essay on Rights (Oxford: Blackwell, 1994).

${ }^{13}$ Janet Coleman, "Pre-Modern Property and Self-Ownership before and after Locke: Or, When Did Common Decency Become a Private Rather Than a Public Virtue?", European Journal of Political Theory 4 (2005): 125-45, p. 127. 
In addition to Arguments 1 to 4, variations on these templates are possible, paralleling the same basic moves. In some respects, these variations are more important than the arguments canvassed above, and I outline three such variations below.

First, each of the arguments presented could be made with a weaker conclusion. For example, rather than absolutely foreclosing welfarist taxation, natural property rights could be argued to at least amount to the creation of a prioritization of property rights, and a resulting presumption against, welfarist taxation. ${ }^{14}$ Some welfarist taxation may survive as a 'necessary evil,' but the onus of justification is placed on such intrusions into the realm of property. (I will argue in the final section of the article that a weakened version of this argument is correct, but that terms such as 'prioritization' and 'presumption against' are misleading.)

Second, the term 'natural right' may be replaced by 'constitutional legal right', 'international human right' or the 'pre-legal notion of a right' in Arguments 1 to $4 .{ }^{15}$ In this way, constitutional recognition of a legal right to property may be seen to foreclose, or at least create a powerful bulwark against, any restrictions, regulations and expropriations of property by the state.

Third, the arguments can apply to different sorts of property. For instance, there is a common refrain in intellectual property literature to the effect that allowing a natural

\footnotetext{
${ }^{14}$ These concerns with presumption and priority are foregrounded in Murphy and Nagel, Myth of Ownership and Sampford and Wood, "Priority of Property".

${ }^{15}$ Oberdiek, "The Infringing/Violating Distinction"; Sampford and Wood, "Priority of Property" pp. 183-4.
} 
property right in the fruits of one's labour to justify copyright - or even merely to understand copyright law as granting 'property rights' rather than a series of highly specified legal privileges - makes exceptions to the reach and content of copyright (e.g. fairuse provisions and sunset clauses) much harder to justify. ${ }^{16}$

This article will argue that Arguments 1 to 4, and all the variations of them specified above, are unsound, and for the same reason. They all rely on a suppressed premise - an un-argued assumption - that it is possible to read off the content and scope of a 'natural' right (or a constitutional legal right) from the 'core concept' of a right. That is, each of these arguments assumes that one can fashion the type of right where one can delineate the legal entitlements granted and the duties imposed from a prior conceptual analysis of the idea of the right. In terminology that I will explain below, the arguments assume it is possible to equate a 'situated' or 'specified' right with the 'core concept' of the right. It is this assumption in Arguments 1 to 3 that allows each argument's premise concerning the 'core concept of the right' to contribute to its stated conclusion about natural property rights and, in Argument 4, allows its first premise about natural rights to connect with its second premise about the 'core concept' of the right. In what follows, using property and free speech as examples, I will argue that this assumption is mistaken, and indeed is obviously mistaken. The type of conceptual analysis theorists perform to establish the core concept of a right deliberately (and sometimes explicitly) sets aside several distinct types of considerations that are plausible (in some cases ineluctable) constraints on all natural rights. The philosophical problem engendered is not with the method of conceptual analysis

\footnotetext{
${ }^{16}$ Carys J. Craig, "Locke, Labour and Limiting the Author's Right: A Warning against a Lockean Approach to Copyright Law", Queen's Law Journal 28 (2002): 1-60.
} 
employed, but rather with taking the result of such an analysis to illustrate the lineaments of a natural or constitutional right - a task for which that result is altogether ill-fitted.

To clarify one point at the outset, the argument of this article is not that it is impossible (or even difficult) to derive the 'core concept' of a right. ${ }^{17}$ With respect to property rights, I accept that there is a core concept of the right to property, and I agree that it does not include a liability for expropriation through taxation. The problem, rather, is with the subsequent misuse of that core concept in moral argument.

${ }^{17}$ See Barbara Fried, "Left-Libertarianism: A Review Essay", Philosophy and Public Affairs 32(1) (2004): 66-92, 72-8. Barbara Fried, "Left-Libertarianism, Once More: A Rejoinder to Vallentyne, Steiner, and Otsuka", Philosophy and Public Affairs 33(2) (2005): 216-22, 216-9. Analogues of several of Fried's objections to left-libertarianism appear in this article, but the core argument differs. Fried argued that the concept of property cannot take the load required of it by (left-)libertarians because it has insufficient substance or determinacy. To the contrary, I am arguing that the concept cannot take the load irrespective of its substance and determinacy. The difference is material, since Fried's argument rests upon what she takes to be the received contemporary view on property; namely, the Realist-cumFunctionalist-cum-Coasean picture. I take this view of property to be mistaken, and - $a$ fortiori - to be an increasingly marginal view in contemporary property theory. On this point, as well as the references in n. 26 below, see also James Penner, "The 'Bundle of Rights' Picture of Property", UCLA Law Rev. 43 (1996): 711-820; Thomas Merrill and Henry Smith, "What Happened to Property in Law and Economics?", Yale Law Journal 111 (2001): 357-98. 


\section{Rights: From concept to conclusive}

The term 'right' carries a veritable hornet's nest of ambiguities. ${ }^{18}$ Sometimes, the term is used to speak broadly about a basic type of freedom worth protecting, recounting the benefits or choices of the right holder that it facilitates. At other times, a speaker might need to specify further, to ensure that the freedom invoked could be vested in all people, and institutionally protected. In a further context, a speaker might want to delineate the entitlement as it might be situated in a larger regime of rights, among other rights, each facilitating and constraining others. Alternatively, the speaker might consider what happens in difficult, extraordinary and highly contextualized situations when two rights conflict. Mapping an inter-related dimension, sometimes rights can be invoked as the premise of a moral argument, urging the audience to accept certain conclusions: "If you accept the right of free speech then you must accept our entitlement to speak out on this matter against the government." At other times, rights are understood as the legal conclusions of prior arguments: "Legislation grants us certain entitlements to speak out against the government. Therefore we have a right to free speech in this context."

The word 'right' can be legitimately invoked in each of these types of discourse, but problems arise when we shift unreflectively from one usage to another. The following fivepart taxonomy provides the conceptual and terminological resources to distinguish these

\footnotetext{
${ }^{18}$ Some of these ambiguities are well known, such as the differences between Hohfeldian claim rights and liberties/privileges, which are for the most part appropriately distinguished when necessary.
} 
different notions of a 'right', and to consider the relations between them. ${ }^{19}$ This section outlines the basic distinctions; later sections provide examples and arguments for their significance.

I hope to convince the reader that something like the following distinctions are essential to a proper understating of rights. The reader may disagree with exactly how I have delineated 'prima facie rights', perhaps, or in the way I have attributed moral force ('violation', 'infringement', 'balancing') to the limitations shaping each of the five groups. Reasonable disagreement on such matters is possible, and I have tried to flag areas of controversy. Such disagreement, however, needs to be separated from the more fundamental point that some distinctions are required, one way or another, to avoid conflation of the abstracted 'core concept' of a right with the final fully-specified right whose entitlements should be secured by law.

Caveats aside, the five 'notions' (as I will term them) of a right are the 'core concept' of a right, the 'coherent right', the 'prima facie right', the 'situated right' and the 'specified right'. Each of these is discussed below.

\footnotetext{
${ }^{19}$ The taxonomy will also be helpful in cases where it is argued that rights - properly speaking - are only conclusive, and cannot serve as premises in politico-legal argument. See, e.g., Onora O'Neill, "The Dark Side of Human Rights", International Affairs 82(2) (2005): $427-$ 39, pp. 429-33. By describing core concept, coherent and prima facie rights, the taxonomy illustrates the form and theoretical significance of these sorts of 'aspirational' rights. It is, of course, still open to theorists such as O'Neill to argue that these aspirational notions of rights do not map on to any actually existing moral entities, but at least the point of dispute will be clarified.
} 


\section{The core concept of a right.}

The core concept of a right is an account of what the right, at the most basic level, allows people to do: the basic type of freedom that the right aims to secure, and the basic types of threat to that freedom that the right protects against. The core concept is an 'ideal type', abstracted from any contextual modifications. Its substance is exclusively positive in the sense that it speaks of the freedoms secured by the entitlement - the benefits and choices it facilitates or provides - and not of any restrictions that might be imposed upon that freedom. In a nutshell, the core concept of a right tells us what the right does for the people who hold it.

\section{The coherent right}

The coherent right is a right that can conceivably form a part of a system of rights; it is at least logically possible that a right holder could hold such a right, when emplaced in a world where that right was protected for her and all others.

The coherent right may differ from - and be more constrained than - the core concept of a right in three respects. First, the coherent right cannot be of such strength or content that it is inconsistent with others holding the same type of entitlements. The coherent right therefore must be constrained by consistency - it must be compatible with others holding the same right. The second and third constraints shaping the coherent right are more controversial - some theorists will see them as being logical requisites of a right; others will not. Second, the coherent right must be universalizable; its substance does not preclude the possibility of all people having the right. Third, the coherent right does not foreclose the institutional requirements of its protection. For example, if we think that property 
entitlements must be protected by the state in order to qualify as a right, then we will think that the coherent right of property must be structured such that the entitlements it vests do not preclude the state from being able to carry out this protection. Hence, the right to property might need to allow room for taxation to fund the state's basic policing and protection of property rights.

In sum, because it does not in any way preclude the conditions of its own universal existence and protection, the coherent right can be used as a premise in a natural rights argument, without being accused of any sort of logical contradiction.

\section{The prima facie right}

The prima facie right is a more nuanced version of the coherent right, inasmuch as it introduces 'paradigm cases' of the right, and avoids licensing actions that are obviously harmful to others.

In terms of paradigm cases, the prima facie right links the entitlements of the coherent right with the human interests or choices that the right was designed to facilitate or promote. John Rawls refers to such paradigm cases as 'fundamental cases' that fall inside a right's 'central range of application. ${ }^{20}$ For Rawls, the fundamental cases and the central range of application are tightly linked to the justification for the liberty in question. For example, Rawls views personal property as a right because of its links to a sense of personal

\footnotetext{
20 John Rawls, "The Basic Liberties and Their Priority", Tanner Lectures on Human Values III (1982): 3-87, pp. 9-12, 47-50. While Rawls is not considering natural rights per se, his theory does imply an array of what are effectively constitutional rights (his 'basic liberties'); hence, his development of resources to deal with potential conflicts amongst them.
} 
independence and self-respect. ${ }^{21}$ More generally, the paradigms are 'obvious cases,' where there tends to be widespread and intuitive agreement about the importance of a right in a particular context. $^{22}$

The prima facie right is also made more normatively attractive by precluding cases where the unconstrained coherent right might allow direct harms to others. This constraint-onharm does not go as far as to comprehensively work through all the limitations that all other natural rights will impose on the right (which is the role of the 'situated right' below). Rather, the prima facie right contains provisions that foreclose the most basic forms of violence, abuse and exploitation that the coherent right might be seen to license.

Through both the prioritization given to the paradigm cases, and the exclusion of obviously harmful cases, the prima facie right creates contours in the map of the right's scope and substance. That is, some parts (harmful applications) of the coherent right are cut away, while other parts (the paradigm cases) are attributed extra importance. A map of the scope of the coherent right would show only which situations were and were not covered by that right; in contrast, a map of the scope of the prima facie right would have more detail, including contour lines highlighting the right's most attractive applications, and deemphasizing or hiving off cases where the right would otherwise counter-intuitively license harms. These contours make the prima facie right more attractive than the coherent right as a premise in political and legal argument.

\footnotetext{
${ }^{21}$ Ibid., p. 12.

${ }^{22}$ See Moreso's 'paradigmatic cases': José Juan Moreso, "Ways of Solving Conflicts of Constitutional Rights: Proportionalism and Specificationism", Ratio Juris 25(1) (2012): 31-46,
} pp. 40-1. 


\section{The situated right}

The situated right includes limitations respecting the full gamut of other people's rights. While the coherent right included constraints with respect to the same right being vested in other people (constraints of compatibility and universalizability), and the prima facie right included constraints foreclosing obvious harms to other people, the situated right is shaped by the application of the full catalogue of other natural or constitutional rights a person holds in a given system of rights. If it is determined that every person has, for example, rights of free association, freedom of religion, freedom of speech and private property, then the situated right of private property will include constraints ensuring that its operation does not vitiate these other rights. Rawls marks this constraint as being one of regulation of a right, as distinguished from a restriction on it: "The priority of these liberties is not infringed when they are merely regulated, as they must be, in order to be combined into one scheme as well as adapted to certain social conditions necessary for their enduring exercise." $^{23}$

In the terms used here, the prima facie right describes the contours of the right as it would function in the absence of the full gamut of specific other rights. When we place a multitude of different prima facie rights into the same normative field, compromises to each prima facie right must be made, and these are reflected in the ultimate shape of the situated right.

\section{The specified right}

\footnotetext{
${ }^{23}$ Rawls, "Basic Liberties" p. 9. See similarly Jeremy Waldron, "Liberal Rights: Two Sides of the Coin", in J. Waldron (ed.), Liberal Rights (Cambridge: Cambridge University Press, 1993), pp. 1-34, esp. p. 25; Waldron, "Filling the Space" esp. p. 109.
} 
The specified right gives an account of ways in which, in exigent situations, the situated right may need to be superseded. ${ }^{24}$ In these special cases, the intrusion on the situated right is understood to be a necessary evil, in what Judith Jarvis Thomson describes as a 'moral residue. ${ }^{25}$ Even when we are sure that the right should be overturned ("the cabin owner's property right should not prevent the travellers caught in a blizzard from seeking shelter therein"), there is, nevertheless, an infraction deep into the situated right that causes moral concern. This infraction on the situated right may cause us to think that compensation should be awarded to the right holder whose right was infringed ("if possible, the travellers should replace the food and fuel they used in the cabin"). Or it may mean that the state is obliged to search for further solutions that, in the future, will allow the exigency to be assuaged without infringement of the situated right. (The category of the specified right is controversial, and those rights theorists who reject it will take the situated right as fully conclusive.)

\footnotetext{
${ }^{24}$ There are further categories after the specified right that could be included in a complete taxonomy. For instance, the legal right might differ (slightly) from the specified right inasmuch as it may have to incorporate complexities arising from the workings of the police and judicial institutions. More importantly again, the notion of the actual right tells us how much the right (or for whom the right) is in fact protected on the ground in a given circumstance or jurisdiction. Merely because a right appears on thin paper does not mean it results in thick action, to use the apt language of Martin Luther King.

25 Judith Jarvis Thomson, The Realm of Rights (Cambridge, Mass.: Harvard University Press, 1990), esp. p. 122, where she introduces the distinction between infringing and violating a right.
} 
To summarise, and introducing some further terminology, the core concept of the right is shaped by the requirements of logical possibility to create the coherent right. The coherent right is contoured by paradigm cases and harmful cases to create the prima facie right. The prima facie right is balanced by the existence of all other relevant rights to create the situated right. The situated right, in special circumstances, may be infringed (but not violated) pursuant to the specified right. Any further intrusions on the specified right are violations of the right and are politically wrongful.

All these notions of a 'right' have their uses in political theory. The core concept provides an account of the basic type of freedom the right aims to secure. Understanding the core concept helps frame further discourse and analysis of the right. The coherent right is the greatest logically possible instantiation of that right; it is a conceivable 'ideal type' that one could commit to without contradiction. The prima facie right fixes attention on the cases where the right's instantiation is most important, and incorporates restrictions on causing obvious harms. It often functions as a premise in political and legal argument, because it offers a way of speaking about the importance and reasonableness of the right without having to take a stance on the existence and scope of every other right. The situated right, in contradistinction, arises from the compromises that must be made as myriad prima facie rights are incorporated into the same political theory or constitution. The situated right describes what is, in ordinary cases at least, owed to each person, and upon which they should be able to rely. Reflective of its intermediate position in the taxonomy, the situated right can be the conclusion of moral argument (incorporating the demands of a multitude of prima facie rights) or the premise of further argument (helping to determine the bounds of the right in hard cases). Finally, the specified right guides the special cases where one right 
must infringe upon the ambit of a situated right to the extent that moral residue appears. The specified right is fully conclusive; once we have the specified right, we know what must be done even in extraordinary circumstances.

In this way, each notion captures a distinct way of conceptualizing the right, and of deploying the right in moral argument (i.e. as framing device, premise or conclusion). This opens a space for challenging the suppressed premise in the arguments of Section One. The different considerations that are in play in determining each of these five distinct notions of a right imply that one cannot read off the ultimate duties and entitlements by analysis of the core concept of the right. The core concept is an appropriate point of departure for the legal or philosophical examination of a natural right. However, it has not been tempered by the types of considerations (e.g. logical possibility, paradigm cases and the existence of other rights) that would allow it to form part of a larger system of rights. As such, it is untenable as a device for determining people's actual duties in any given case. The core concept of a right, therefore, cannot be equated with a situated or specified right from which it is possible to read off people's entitlements under law. The next three sections provide further arguments for this thesis.

\section{Property theory and the question of harm}

The substance of the core concept of the right to property has been the subject of concerted debate over the past several decades. In the early stages of the twentieth century, and under the influence of legal positivism, it was widely thought that there was, effectively, no core concept of the right to property. 'Property' was held to be no more or less than the specific cluster of entitlements (figuratively termed a 'bundle of sticks') that the law granted to a specific person in a specific case in a specific jurisdiction. While still 
present today, property theory in political and legal philosophy has mostly turned away from this deflationary 'bundle theory.' An array of works over the last half-century have argued that property has an integrated and determinate core concept, with analysts usually centring on elements of use, exclusion and disposition. ${ }^{26}$ Of specific interest to us here is the question of the prohibition on harm and its incorporation into the core concept of property.

To explain: A. M. Honoré's 1961 account of 'full liberal ownership' is one of the seminal works of twentieth-century property theory. ${ }^{27}$ Honoré famously distilled eleven 'incidents' of property, including such entitlements as the rights to possess, use, manage and so on. The ninth incident was a constraint on using one's property harmfully. ${ }^{28}$ Later property theorists helped themselves to Honoré's remaining incidents, but explicitly spliced off the ninth. They had their reasons for doing so, arguing that a prohibition on harm is hardly peculiar to property - it is a prior duty imposed on everyone, irrespective of their status as

${ }^{26}$ See, with variations at the margins, A. Honoré, "Ownership", in A. Guest (ed.), Oxford Essays in Jurisprudence (London: Oxford University Press, 1961), pp. 107-47; James Harris, Property and Justice (Oxford: Oxford University Press, 1996), 119-38; J. Penner, The Idea of Property in Law (Oxford: Clarendon, 1997); Thomas Merrill, "Property and the Right to Exclude", Nebraska Law Review 77 (1998): 730-55; Jeremy Waldron, "What Is Private Property?", Oxford Journal of Legal Studies 5 (1985): 313-49; Adam Mossoff, "What Is Property?", Arizona Law Review 45 (2003): 371-443.

${ }^{27}$ Honoré, "Ownership".

${ }^{28}$ Ibid., pp. 122-3. 
property holders. ${ }^{29}$ Equally, the prohibition on harm is not part of the right of property in the sense that it is not a right of Alf's (the property holder) that he cannot use his property in ways that harm Betty. If anything, the right in that case is Betty's, not Alf's.

But Honoré had a point too. After all, he was not referring to contingent or voluntary alterations to specific individuals' property entitlements, but rather to consistent, universal constraints that apply to all instances of property. Presuming that the right to property is being emplaced in a recognizable theory of rights, or in a recognizable rights-respecting legal regime, people will not be allowed to use their property to directly harm others. Nobody thinks otherwise. Yet if the prohibition on harm is, for this reason, an essential feature of the right to property, then it makes perfect sense to include reference to it when giving an account of that right.

The distinctions introduced in Section Two give us the conceptual resources to explain what is going on here. Property theorists after Honoré have focused on the core concept of the right to property; they aim to give us an account of the freedoms the right to property offers to the right holders. No mention of the rights of others is necessary for this purpose. Honoré, on the other hand, was providing an account of what I have termed the prima facie right of property. If the prohibition on harm is an essential feature shaping the scope of the right of property - as everyone of course agrees it is - then it is worthy of inclusion in an account of the right of property.

\footnotetext{
${ }^{29}$ E.g. Christman, "Self-Ownership" p. 45; Attas, "Fragmenting Property" p. 140; Waldron, "What Is Private Property?" pp. 320-1.
} 
The implications of this dispute for the target arguments described in Section One are rarely noted. For this point of distinction makes clear that there is, on all accounts, a difference between the core concept of the right to property (i.e. exclusion, use and disposition) and the right to property that can be situated in a larger natural or legal rights topology. The latter, but not the former, includes a constraint on harmful use of one's property. For this reason, the suppressed premise in Arguments 1 to 4 must be rejected. For now, it turns out that we simply cannot read off the content of a natural right from the core concept of a right. No property theorist is willing to say that property rights must rule out a prohibition on harmful use, because that prohibition is not found within the prior core concept of property. Nor is a theorist willing to say that property rights must rule out a prohibition on harmful use, because such a prohibition is in flat contradiction with the view that property holders can, at their discretion, determine the use of the resource. Nor do they even attempt the more mitigated claim that - while of course necessary and justifiable - duties not to harm nevertheless strictly speaking infringe upon the right to property, and are for this reason a necessary evil; therefore, there must be an onus of justification on such duties not to harm. To the contrary, all property theorists accept as a matter of course that the right to property shapes itself as it overlays across a landscape of pre-existing (or at least contemporaneous) background duties prohibiting harm. Expressed in the terminology of Robert Nozick, prohibitions on harm have already filled some of the space of rights, and rights to property can at best deploy into the remaining space. ${ }^{30}$ As a general matter, then, the suppressed premise of Arguments 1 to 4 - that we can read off the substance of the natural right from the core concept of a right - is demonstrably false.

\footnotetext{
${ }^{30}$ Nozick, Anarchy, State, and Utopia, p. 238.
} 
The presence of duties prohibiting harm in the natural right to property, but not in the core concept of the right, moves the issue of prior duties decisively to the foreground. Through parity of reasoning, if we have prior duties to help needy others, say, then it cannot be maintained that these duties of expropriation are ruled out by the fact that they are not found within, or are in some cases in conflict with, particular elements of the core concept of property. As has just been observed, a similar situation is found with prohibitions on harm. ${ }^{31}$ We cannot move from affirming the natural right of property to the non-existence of welfarist duties, any more than we can move from accepting the natural right to property to the non-existence of duties prohibiting harm. The fact that neither set of duties is found within the core concept of the right to property is irrelevant in both cases.

Of course, it might be independently argued that we do have duties not to harm others, but we do not have duties to help them. But that is exactly the point. Independent arguments must be marshaled to support this stance; we cannot determine the non-existence of such duties simply from observing the core concept of the right to property - as Arguments 1 to 4 imply.

\section{From concept to conclusive: The right to free speech}

In the case of free speech, it is difficult to find anyone who attempts to read off the natural or constitutional right of free speech from the core concept of the right. Not only is free

\footnotetext{
${ }^{31}$ In a later work, Honoré himself anticipated this move from the incorporation of duties prohibiting harm into the right of property, to the incorporation of liabilities to taxation; A. Honoré, "Property and Ownership: Marginal Comments", in T. Endicott, J. Getzler, and E. Peel (eds.), Properties in Law: Essays in Honour of Jim Harris (London: Oxford University Press, 2006), pp. 129-37, p. 134
} 
speech constrained by other rights, but the constraints on it are so powerful and wellentrenched that it can be difficult to even recognize them as exceptions. Consider for a moment the core concept of freedom of speech - its 'pre-legal concept' ${ }^{32}-v i z$. one person being able to express what they want to others without being legally prohibited from speaking or being punished for what they say. As innumerable commentators have observed, if we were to immediately read off the right to free speech from this core concept, then we would allow not only slander, libel, obscenity, hate speech, fighting words, defamation, the misuse of secret and dangerous information, the violation of privacy, and the dissolution of copyright and trademark, but also perjury, misrepresentation, false advertising, solicitation of crime, complicity by encouragement, conspiracy, threat, fraud and the violation of contract. ${ }^{33}$ In extreme cases, we would even allow communication that is used to kill: Justice Holmes' famous example of shouting 'fire' in a crowded building to cause a violent panic was no mere theoretical speculation. ${ }^{34}$ The fact that free speech is constrained in all these ways - at least some of them surely justifiable - is evidence that free

\footnotetext{
32 Lawrence Alexander and Paul Horton, "The Impossibility of a Free Speech Principle", Northwestern University Law Review 78(5) (1984): 1319-57.

${ }^{33}$ Ibid., pp. 1351-2; C. Edwin Baker, "Harm, Liberty, and Free Speech", Californian Law Review 70 (1997): 979-1020, pp. 982-4; Robert C. Berness, "Norms of Judicial Behavior: Understanding Restrictions on Judicial Candidate Speech in the Age of Attack Politics", Rutgers Law Review 53(4) (2001): 1027-61, p. 1039; Richard Epstein, "Property, Speech and the Politics of Distrust", University of Chicago Law Review 59 (1992): 41-89 pp. 45, 60, 70-5. ${ }^{34}$ Baker, "Harm, Liberty, and Free Speech" p. 982.
} 
speech, like property, deploys into a larger normative field where such norms as the protection from harm and the power to contract have their own force.

The point can be illustrated by categorizing free-speech rights into the five notions developed in Section Two:

1. The core concept of the right to free speech: the core concept of the right to free speech is that a person is at liberty to express what they want without threat of legal interference or sanction.

2. The coherent right to free speech: the coherent right includes any limitations that are necessary to ensure that all others can similarly have the right, and - arguably - any limitations that are necessary to ensure its institutional protection. In terms of the former (limitations allowing compatibility and universalizability), theorists such as Rawls and Meiklejohn hold that certain rules of order are essential to regulate free discussion, given that not everyone can speak at once in a way that will preserve the substance of the right. ${ }^{35}$ If that is right, then the coherent right to free speech will include these limitations in its working. In terms of the latter (limitations necessary to give institutional protection to the right), it might be thought that a functioning justice system is required to ensure the legal protection of speakers. Plausibly, such a system will require rules of contract and prohibitions on perjury; the institutions of justice cannot function if people such as judges, police and prison guards cannot be relied upon to do what they formally undertake to do, and if witnesses are not required to tell the truth about what has happened in the past. A coherent right of free speech would therefore also include these limitations.

\footnotetext{
${ }^{35}$ See Rawls, "Basic Liberties" pp. 9-10.
} 
3. The prima facie right to free speech: the prima facie right will contour the coherent right by developing paradigm cases of application, and foreclosing obviously harmful uses of speech. Paradigm cases might include, for example, the expression through peaceful demonstration of political viewpoints antithetical to those of the prevailing authority, or the assertion of believed truths (e.g. of scientific hypotheses) that clash with received opinions. Proscriptions on harm will include at least the most obvious cases of threat, fraud, solicitation of crime and violation of contract.

4. The situated right to free speech: the situated right makes space for the demands of all the other rights recognized by the constitution or the natural rights theory. Hence, the situated right may include, for example, nuanced prohibitions on defamation (balanced to align with the right of personality or reputation), prohibitions on competitive reproduction of original expressions (balanced to align with rights of copyright) and prohibitions on 'fighting words' (balanced to align with the right to life). ${ }^{36}$

5. The specified right to free speech: the specified right to free speech will include limitations specific to certain contexts, where it is arguable that the right may need to be infringed due to exigencies of the situation. An example from international law is the set of derogations from the right to speech allowed in situations of national emergency by human rights instruments such as the International Covenant on Civil and Political Rights. ${ }^{37}$ Pursuant to its

${ }^{36}$ Some legal instruments explicitly recognize these types of limitations on the prima facie right of free speech: E.g. Art. 19(3) of the UN General-Assembly, International Covenant on Civil and Political Rights (ICCPR), E/CN .4/1985/4, 16 December 1966; Art. 1, Section 8, Clause 8 ("Copyright Clause") of the Constitution of the United States.

${ }^{37}$ ICCPR., Art. 4(1). 
Art. 4(1), states can formally derogate from Art. 19(2) - providing for the right to freedom of expression - in situations of emergency. But, even in such situations, the right is not wholly abrogated, and legal conditions govern the extent to which infringements of the situated right are allowable. ${ }^{38}$

As this analysis reveals, both in theory and law, the distinctions between the core concept of free speech and the situated or specified rights of free speech are implicitly understood and used. No one believes that the natural rights theorist or constitutional lawyer is forced to read off the ultimate duties and entitlements arising from the right to free speech from the core concept of free speech. To the contrary, it is taken for granted that the situated right to free speech will differ in pivotal ways from the core concept, most obviously in not including a license to use speech to defraud, slander or threaten.

The thesis of this article is that, in the context of natural property rights, theorists should not presume that final legal entitlements can be read off the core concept of property. Free speech provides a clear example of a case where this presumption of equivalence between core concept and specified right is not made - and could not be made without wholesale revision of laws of contract, fraud, slander and intellectual property. If this rejection is

\footnotetext{
${ }^{38}$ For example in the form of the constraints in Art. 4(1) and the UN Commission on Human Rights (UNCHR), The Siracusa Principles on the Limitation and Derogation Provisions in the International Covenant on Civil and Political Rights, E/CN.4/1985/4, 28 September 1984.
} 
correct in the context of rights of free speech, then it stands to reason it is correct in application to rights of property. ${ }^{39}$

\section{From concept to conclusive: property rights}

Just like free speech, property rights can be categorized into five distinct notions, as shown in this section. In illustrating how the five notions differ from one another, with increasing constraints on the right as it moves from concept to conclusive, I use examples from natural rights theory (especially Locke) and from property law. But these examples are only illustrative - debate is possible about the cogency of each of them. For instance, the reader might hold that the coherent right need not include such a strong notion of universalizability, or disagree on the 'paradigm cases' suggested for the prima facie right, and so on. Again, the non-negotiable point is that there must be some constraints (e.g. arising from concerns with harm, logical possibility and universalizability) that make the final legal right more constrained and contextualized than the initial core concept.

1. The core concept of the right of property: the core concept of the right of property (in X) comprises the entitlements to use $\mathrm{X}$, to exclude others from using or harming $\mathrm{X}$, and to dispose of $X .^{40}$ These capacities for use, exclusion and disposition are the basic freedoms granted to the property holder, and describe the basic threats (against trespass and harm) that the property right aims to defend against.

\footnotetext{
${ }^{39}$ Unless, of course, specific reasons can be provided to show that property - or perhaps expropriation of property - is relevantly different, for which see $\S \mathrm{VI}$.

${ }^{40}$ See, broadly, the references in $\mathrm{n} .26$ above. Theoretical disagreement remains within the parameters of this tripartite model, particularly regarding whether use or exclusion constitutes the essence of the property right.
} 
2. The coherent right of property: the coherent right includes those constraints that allow the right to be vested in all people, and to be appropriately protected. At a minimum, this includes prohibitions on using one's property to visit harms on other's properties. In common law this constraint is found in the ancient principle of sic utere tuo ut alienum laedas: "Use your own so as to cause no harm." ${ }^{41}$ More generally, the right will incorporate concerns against creating obvious nuisances and 'spite fences.' Arguably, the coherent right will also need to contain those measures necessary to sustain the institutions of justice that can police and adjudicate disputes on the property rights - including perhaps the liability for taxation necessary to pay for these.

Natural rights theories of property (as distinct from constitutional property rights) may impose more substantial constraints at this point, because they typically use 'principles of justified appropriation' to explain how private property initially comes to be owned. These principles of appropriation, in order to be universalized, incorporate provisions ensuring that non-appropriators are not having their capacities for appropriating property unjustifiably abridged by these initial appropriators. ${ }^{42}$ The classic example here is of course the Lockean proviso, to leave "enough and as good" for others. ${ }^{43}$

\footnotetext{
${ }^{41}$ See Freyfogle, Land We Share, pp. 67-83.

${ }^{42}$ For discussion of these principles, especially with respect to their universalizability, see, e.g., Nozick, Anarchy, State, and Utopia, pp. 175-81; Hugh Breakey, "Without Consent: Principles of Justified Acquisition and Duty-Imposing Powers", The Philosophical Quarterly 59(237) (2009): 618-40, pp. 627-32.

${ }^{43}$ John Locke, Two Treatises of Government (New York: Hafner, 1947), Sec. II:33, 36.
} 
3. The prima facie right to property: the prima facie right emphasizes the paradigm cases of property ownership. The family home is perhaps the most obvious paradigm of a property right ("a man's home is his castle"), but many other intuitive figures are possible, as a skim through Chapter Five of Locke's Second Treatise reveals. A paradigm case of property in labour might be located in the popular folk tale of the "little red hen", who makes bread from a grain of wheat she finds, and asks the other animals to help her plant, harvest, thresh, mill and bake. The other animals are lazy and do not help her, and when the bread is finally baked, she elects not to share it with them. The theme of the story is the little red hen's entitlement not to share - that is, her property rights in her labour and its fruits. Harmful uses of property are also foreclosed at the stage of the prima facie right. Here, the point is not merely to preclude harms to other's properties (as the coherent right required) but also to not endanger other's bodies and lives through one's actions in using the property - especially if the owned object is a sports car or gun, for example. Equally, nobody believes that property entitles one to say and do whatever one likes on one's property if that means committing breach of contract or fraud. This point is so obvious that it is easy to miss, but it is a clear case of property deploying into a normative field already populated with duties of contract.

4. The situated right to property: the situated right includes concessions to all the other natural rights in a given theory of rights or legal system. An example from law would be situations where rights of property and free speech impact on each other, for instance in the 'mall cases.' In these cases in the common law world, courts have moved to define malls as 'quasi-public' spaces, in the sense that the mall has come to serve a purpose similar to public meeting places such as town squares. Courts held that a paradigm case of the prima 
facie right to free speech was the ability to share one's views in public places, for instance by giving out political pamphlets. As such, the courts held that the right of the propertyowner must be circumscribed to allow for such political expression. ${ }^{44}$ Similarly, the right of non-discrimination can shape the right to property, by (in another legal example) prohibiting shop owners from excluding people from their establishments solely on the basis of their skin color. ${ }^{45}$ These are examples of balancing the property right to cohere it with other negative rights. If the natural rights theory or the constitution contains positive or welfarist rights (e.g. a 'right to food'), then it is at this juncture - as the situated right is being identified - that the natural property right would be shaped pursuant to such welfarist rights.

5. The specified right to property: the specified right to property includes infringements on the situated right that may be necessary in special or emergency situations. An example of an emergency situation where the right to life needs to impinge on the situated right of property would be the way property in law grants a type of usufruct for non-owners to use others' property to shelter in emergency situations. For instance, the right of property allows boat owners the liberty to use a private pier to shelter from a storm. A theory-based example concerns the exceptions carved into property rights by the 'right of necessity' for the starving or desperate. Such a right, and its inter-relation with the natural right of

\footnotetext{
${ }^{44}$ Kevin Gray and Susan Gray, "Private Property and Public Property", in J. McLean (ed.), Property and the Constitution (Oxford: Hart, 1999), pp. 11-39, pp. 20-31.

${ }^{45}$ Joseph Singer, Entitlement (London: Yale University Press, 2000), pp. 39-44.
} 
property, was present from the very beginnings of natural rights theory in the seventeenth century, appearing in a variety of forms in Pufendorf, Grotius and Locke. ${ }^{46}$

As the analysis shows, these situated and specified rights are a substantial distance from the core concept. At each step in the process, the right acquires more of the characteristics that allow it to form one part of a functioning system of rights.

I mentioned earlier that, while it is possible at times to read Nozick as propounding Argument 4, where welfarism is foreclosed by prior natural property rights, at other places he is sensitive to the way natural rights need to be shaped to take their place in a larger system of rights. His treatment of the Lockean proviso is a case in point. Nozick sees the central core of the notion of a property right in $\mathrm{X}$ as, "the right to determine what shall be done with $\mathrm{X}$; the right to choose which of the constrained set of options concerning $\mathrm{X}$ shall be realized or attempted." ${ }^{47}$ This definition does not appear to leave room for a property right non-consensually changing into a lesser entitlement, and certainly not for the complete expropriation of one part or the whole of the property right. (The extinguishing of a property right over some object is not the same as choice within a constrained set of options regarding that object.) Yet Nozick allows that the shadow of the Lockean proviso the 'enough and as good' conditions under which property can be rightfully appropriated can require such changes in the entitlement. In Nozick's version of Locke's proviso, an appropriation is legitimate only if it does not worsen the situation of others by reducing (the

${ }^{46}$ Stephen Buckle, Natural Law and the Theory of Property: Grotius to Hume (Oxford: Clarendon Press, 1991); Locke, Two Treatises, I:42; John Locke, "Venditio", in M. Goldie (ed.), Political Essays (New York: Cambridge University Press, 1997), pp. 339-43.

${ }^{47}$ Nozick, Anarchy, State, and Utopia, p. 171. 
net total of) what they can use, in particular, what they need to use for the preservation of their life. ${ }^{48}$ Nozick gives an example in which someone legitimately appropriates a watering hole where there are several other water holes nearby. Later, however, those other water holes dry up. At this point, Nozick holds that the "shadow" of the proviso stringently limits the owner's entitlements over "what it is difficult any longer to unreservedly call" his property. ${ }^{49}$ In other cases, Nozick allows complete dissolution of property rights in things to occur on the basis of the proviso. ${ }^{50}$ As he emphasizes, "considerations internal to the theory of property itself, to its theory of acquisition and appropriation, provide the means for handling such cases." ${ }^{51}$ In other words, Nozick does not simply read off the content of the natural right to property from his own stated core concept of the right to property; he accepts that natural rights theory can require limitations - even liabilities to expropriation on the functioning of the property right. More interesting again, the substance of Nozick's proviso - with its emphasis on access to natural resources that are necessary for life plainly appears to be responding to material human wellbeing, as Jeremy Waldron has persuasively argued. ${ }^{52}$ Expressed in the terms introduced in this paper, the shadow of the

\footnotetext{
${ }^{48}$ Ibid., pp. $176-80$

${ }^{49}$ Ibid., p. 180.

${ }^{50}$ Such as with discoveries of naturally existing therapies, and also inventions (through patent), ibid., pp. 181-2. Nozick's argument that some appropriations may also require compensation to non-appropriators could presumably also require limited expropriation of produce. Ibid., p. 178.

${ }^{51}$ Ibid., p. 180.

${ }^{52}$ Waldron, "Filling the Space" pp. 97-101.
} 
Nozickean proviso determines the way the natural rights to life and productive work balance the natural right of property, as the situated right to property is delineated.

All this has implications for positive rights-based duties to help the needy. Nothing in the above argument purports to show that Lockeans, Nozickean libertarians or 'self-ownership' left-libertarians must accept welfarist duties. However, the fact that all these theorists acknowledge that the core concept of property does not determine the ultimate, situated natural right of property (because they all accept restrictions on harmful uses, and some version of the Lockean proviso) opens a conceptual space to inject precisely such duties. The space is opened because the fact that these positive duties would impinge in various ways on the core concept of the property right cannot be decisive against their existence otherwise the same consideration would be equally decisive against the proviso-based and harm-based limitations these theorists themselves accept. As such, the theorists cannot appeal to the content of natural property rights or self-ownership to justify their rejection of these duties.

\section{Objections and implications}

\section{The 'carte blanche' objection}

An immediate objection to the argument of this article is this: if natural property rights don't preclude positive duties to help others, doesn't that mean anything is possible? And if it is - if any sort of natural right could conceivably introduce duties and limitations into the substance of the natural property right - then won't we be left with a radically indeterminate, and hence effectively useless, political theory? 
The short answer here is that anything is not possible. It is certainly true that one can imagine putative 'natural rights' that cut directly against the grain of a right to property. For instance, having a natural right to 'ongoing egalitarian distribution of resources' is antithetical to a natural property right. Every single choice and action enabled by the property right, including in its paradigm cases, presses against such patterned outcomes. Choices of use vary in prudence, work ethic, productivity, foresight and riskiness; choices of exclusion vary in who else takes actions on the property and their trustworthiness, complementarity and productivity as they do so; and choices of disposition vary with respect to all manner of market vagaries. All these baseline features of the property right tell against ongoing egalitarian outcomes. Indeed, it is not only liberty that upsets patterns, but brute luck. In property, as in many other negative rights, the chips are allowed to fall where they may. A person may not deserve their good luck or their misfortune, but property boundaries entitle them to the result of it. A right to such a patterned outcome therefore could not be aligned with the natural right to property; it subverts its operation even in the paradigm cases.

The situation is entirely parallel with respect to free speech and other natural rights. One can conceive of rights that cut directly against the paradigm cases of free speech. For instance, citizens could be vested with a right that nobody impinges on their dignity by using words that undermine national interests or the people's solidarity, or that disseminate illegal, wrongful, blasphemous and unethical viewpoints. In such a case, authorities could speak of a 'bundle theory' of free speech, where the legal 'rights' regarding freedom of speech were just the specific speech entitlements the regime granted to a given individual in a given situation. But it would be hollow to speak of a natural or constitutional right to 
free speech in this case; nothing worthwhile remains in the right once it is opposed with the conceived right. As with property, so too with free speech. The allowance that other rights can shape the situated right does not mean that every other conceivable right can sit alongside it.

In any case, we would not expect a coherent natural rights theory to invoke antithetical rights. To say that all people are owed a right to free speech is simply to say they are not owed a right that others refrain from expressions that undermine the people's solidarity. To say that all people are owed a right to property is simply to say that they are not owed a right to ongoing egalitarian leveling. Any given account of natural rights will arise from deeper philosophical fundaments regarding elements such as human freedom, rationality and the good life. As the outcomes of such theorizing, these rights are bound to be, in some sense, integrated, and therefore workably compatible.

\section{The 'expropriation is different' objection}

Even if all that I have argued is correct, it may yet be contended that, at best, it shows only that natural property rights can be regulated in various ways. Expropriation through coercive taxation, it could be charged, is a different matter entirely. Suppose Annie owns Blackacre, and farms some corn on it. Suppose also that the specification of her right of property (e.g. regulated by other's rights of food) requires that some of the corn be provided to the needy. In such a case, Annie unquestionably loses the property she held in some of the corn. But this objection urges that situating property among other rights can only mean that the property can be regulated and constrained (as other rights are). It does not include the possibility that Annie can actually lose the right itself, which is what happens when expropriation of her property in the corn occurs. This objection does not rest on the 
presumption (which I have argued is mistaken) that situated rights are equivalent to core concepts. It willingly grants that balancing of rights can require delimitation and regulation of those rights. Instead, what the objection asserts is that it is one thing to say that a situated right can be regulated, but quite another to say that balancing can dissolve the right altogether, as happens with the portion of Annie's corn expropriated for the needy.

There are, however, serious problems with this objection. ${ }^{53}$ First, if expropriation is, on this basis, a problem with taxation for the needy, it is equally a problem with taxation for the minimal state. Even libertarian specification of the right to property requires that some property rights over some objects will be expunged for this purpose.

Second, it remains to be shown why expropriation of one particular physical slice of a person's property through taxation is more worrisome or conceptually problematic than, for example, the expunging of one particular time slice of a person's right to free speech when they are served with a subpoena to give evidence in court. In each case, we can bundle together a group of entitlements ("property over the subset of corn harvested" and "entitlements to speak freely over a set period") that are completely extinguished. In each case, plausibly, it is the impact on the larger rights - to free speech over a lifetime and to property in Blackacre in its entirety - that matters when specifying a right. Arguably, limited expropriative liabilities on produce are an appropriate type of limitation to be imposed on people's rights to specific parts of the world, just as temporary but comprehensive

${ }^{53}$ One minor point; it is not as if Annie's property in the corn is simply dissolved with no remainder. Rather, Annie's prior ownership of the corn allows the expropriation of that corn to pay her dues to needy others. The corn is still put to her advantage in that sense; if she did not own it, she would have had to pay her dues in some other fashion. 
restrictions in certain contexts (e.g. the exercise of a subpoena) are an appropriate constraint on rights such as free speech.

Third, and most importantly, 'regulations' can ultimately require expropriations. Recall again Nozick on the shadow of the Lockean proviso. The conditionalization of the initial powers of property appropriation (as they are shaped in conformity with Nozick's Lockean proviso) creates ongoing conditions for the legitimacy of any holdings acquired on its basis. Nozick distinguishes between the status of legitimate property and the status of property claimed in violation of the proviso, and is explicit that holdings can shift from one category to the other, as occurs in his water-hole example related earlier. ${ }^{54}$ In other cases, Nozick allows that compensation and full expropriation of property can occur through the application of the proviso. ${ }^{55}$ In all such instances, the initial right of appropriation is not expunged, only regulated, but this is consistent with the expropriation of a particular piece of property acquired pursuant to that initial right. As such, in the context of natural rights theory, the dichotomy posited by the objection between expropriation and mere regulation collapses. The regulation of natural rights to acquire property can justify later expropriations of individual pieces of property.

\section{The 'weakened' versions}

Earlier, I noted the possibility of 'weakened' versions of the initial arguments. Unlike Argument 4, these arguments are not used to foreclose welfarism. Rather they aim to prioritize property rights, and thereby shift the onus of justification onto welfarist expropriations. The foregoing arguments help illustrate the extent to which this is in fact so.

\footnotetext{
${ }^{54}$ Nozick, Anarchy, State, and Utopia, pp. 179-81.

${ }^{55}$ Ibid., pp. 178, 181-2.
} 
Accepting a natural right to property will restrain welfarist expropriation in three ways. First, as noted above, there are some types of strongly welfarist distributive principles ('ongoing egalitarian distribution') that will be foreclosed by natural property rights. Second, natural property rights will limit, in various ways, the scope and substance of other redistributive rights (e.g. a right to food), as these other rights move from prima facie status to situated rights. For example, in the terms I have introduced, the prima facie right to food will deploy into a normative field alongside the prima facie right to property. Each right will be at once balancing and being balanced, at once constraining and being constrained, by the other. The end result of this process will be the situated rights to both food and property. (Note the symmetrical positions of both rights in this process.) Third, in the 'paradigm cases' of the property right (e.g. with respect to a person's home), there will be an additional pressure pushing back against other rights, because these are understood to be the clearest and most important cases of the right to property. Thus, in these three ways, natural property rights profoundly shape the situated welfarist rights others may have.

But - the objection might go - isn't that just to say that property rights have priority, that there is a special onus of justification on constraints on the property right, which are viewed as necessary evils? It is not. Certainly, if we accept the justifications for the natural right to property, there will be an onus of justification on any other rights that seek to impose constraints on that natural right. However, that is only because there is an onus of justification on every right, and the foregoing sentence posits that we have already been presented with, and presumably been satisfied by, the justification for the right to property. Suppose instead that we have accepted the justifications for the natural rights to property and to free speech, won't it then be true that there will be an onus of justification on the 
right of free speech when it limits the property right? Here the answer is "No." Ex hypothesi, both rights have been justified and their situations are entirely symmetrical. Limitations on free speech by property are no more or less worrisome than limitations on property by free speech. Neither has priority or a special onus of justification, and neither is more of a 'necessary evil' than the other. The same holds for balancing property rights and welfare rights.

\section{The natural right to property and positive duties to help the needy}

Given the above arguments, what would a regime that incorporated both positive duties to help needy others and the right to property look like ${ }^{56}$ While a comprehensive theoretical account is beyond the scope of this article, a quick answer is: "Look around you." Chances are that such a regime would look, roughly speaking, like the political environment in which you live. As the commentators with whom we began in Section One bemoan, ${ }^{57}$ in contemporary developed countries, we live in a world where people's tax duties for welfarist and other purposes are calculated by taking market outcomes and their property holdings as a presumptively just baseline. In such cases, property rights form a superstructure to which duties to contribute to other citizen's health, education and basic welfare are added. The baseline is normatively significant but not conclusive, in just the

\footnotetext{
${ }^{56}$ Waldron makes the important point that welfarist rights need not imply positive (legal) duties. As he argues, both Locke and (indeed) Nozick balance property rights with rights based on material human need, but they do so in terms of constraining or removing the property right, rather than imposing positive duties to act. Waldron, "Filling the Space" $p$.
} 95.

${ }^{57}$ See Murphy and Nagel, Myth of Ownership; Sampford and Wood, "Priority of Property". 
same way as the prima facie right to property is normatively significant but not conclusive;

both wait to be shaped into the situated right by reference to the other rights placed around that right. This baseline does not mean that the property right has priority over these other rights, or that the introduced constraints on the right to property are in any sense 'necessary evils.' One could as well assert that intrusions on the presumptively just right to education caused by the right to property are necessary evils. Each right, equal in value to the others, deploys simultaneously into the same normative space - shaping and being shaped by the other rights as it does so. 'Necessary evils,' on the account of rights provided above, do not occur when prima facie rights are balanced to craft situated rights, but only on the infringement of situated rights that is countenanced by specified rights. It is only with this infringement, and its accompanying 'moral residue,' that talk of 'necessary evils' becomes apt.

The point here is not of course that this balancing and shaping is performed perfectly by existing polities, or that the canon of rights upheld by contemporary developed countries is the same as would emerge from our best theory of natural rights. The point is only that the fact that we live in polities where rights to healthcare and education can be provided without losing a recognizable market economy and property rights in land, homes, chattels and businesses shows that these sorts of welfare rights do not create the direct conflict with natural property rights that a more thoroughgoing egalitarianism would involve.

That said, no words here can deflect the conclusion that, if the argument of this article is correct, natural rights theory should be much messier and more complicated than it currently is. I have aimed to pull the rug out from some basic assumptions that serve to constrain the moves that can appropriately be made in natural rights theorizing - namely, 
that commitments to natural property rights and self-ownership foreclose positive welfarist duties to others.

\section{Conclusion}

This article has argued that it is necessary to make a range of distinctions delineating the particular notion of 'right' that is being invoked. At the most abstract end of the scale are rights as core concepts; these are shaped by the requirements of logical possibility into coherent rights. Coherent rights are in turn contoured by paradigm cases and the exclusion of basic harms. The resulting prima facie rights are then balanced as they are brought into equipoise alongside other rights to create the situated right. In special cases, situated rights can be infringed, as determined by the specified right.

While there are controversial elements at work in aspects of these distinctions, there should be no debate over the rejection of the suppressed premise in Arguments 1 to 4 that a natural (situated or specified) right is equivalent to the core concept of that right. I have argued for this rejection on the bases that, (i) the core concept of the property right does not include restrictions on harm that everyone agrees are present in the natural right of property, (ii) the right to free speech provides an example case where well-accepted exceptions to the core concept are incorporated into the situated right to free speech, and (iii) the use of Lockean provisos by both libertarians and left-libertarians to create the situated right to property introduces a further point of difference between the core concept and the natural right of property. For these reasons, a right from which it is possible to delineate actual legal duties and entitlements cannot be presumed to be the same as the core concept of the right. The suppressed premise in Arguments 1 to 4 must be rejected, and with it the arguments themselves. 
Before concluding, it is important to reiterate what is, and what is not, being argued for here. In this article, I aim to open a viable space for a middling political position, upholding both property rights and welfarist rights, by refuting a set of arguments from the left and right against the tenability of such a stance. This is not the same as arguing that the egalitarian or libertarian positions are wrong or untenable. In particular, a natural rights libertarian can unblinkingly accept the five notions of a right described in Section Two and, by making and arguing for specific choices at each step, develop a situated right to property that allows only the constraints necessary to ensure the compatibility of property rights, prohibitions on harm, and the expropriation required by the minimal state. Nothing here prevents those arguments being made, or questions their likelihood of success. The point of this article is merely that acceptance of a natural right to property or self-ownership does not in itself foreclose the possibility that a situated property right can include liability for welfarist taxation. Ultimately, the argument presented opens theories of natural property rights to the possibility of including welfare rights, but it does not impel such theories to accept those rights.

In conclusion, when polled, laypeople are often found to morally value both property rights and environmental regulation, or both property rights and support for the needy. The arguments presented here contend that, in having such values, citizens are not confused or illogical. There is no 'nationwide paradox in public opinion. ${ }^{58}$ Their views on the compatibility of property rights and welfare rights are not 'incoherent,' 'meaningless,'

\footnotetext{
${ }^{58}$ See the discussion reported by Meyer, "Environmental Imagination" pp. 100-101.
} 
'logically impossible' or 'intellectual confusions. ${ }^{59}$ Quite the contrary. The folk are right and the theorists are wrong. Natural and constitutional property rights preclude neither natural and constitutional welfare rights, nor the more general contextualization and regulation of property for rights-based reasons.

\section{Acknowledgments}

I would like to thank Paul Formosa, Dave Kinkead, Michael Vincent and (especially) Bas van der Vossen for helpfully pointed comments on earlier drafts of this paper.

${ }^{59}$ These charges are all laid against the beliefs of everyday people who believe in both welfarist taxation and the importance of property rights: Murphy and Nagel, Myth of Ownership, esp. pp. 31-7. 